\title{
Paweł Prüfer, Rekonstrukcja jakości życia. Teoretyczno-praktyczne atuty socjologii, Toruń 2021
}

Permanentna zmiana to cecha przypisana światu społecznemu i towarzyszy mu niezmiennie przez tysiąclecia. Dynamika i charakter dokonujących się transformacji uzależnione są od wielu przenikających się uwarunkowań: jakości i złożoności wykształconych struktur hierarchicznych, stosunków zachodzących pomiędzy mikro- i makrostrukturami społecznymi, złożoności wspólnot kultury i hierarchii panujących w niej wartości, czy też wreszcie - od morfologii społecznej (ekologii społecznej) $)^{1}$ oraz czasu społecznego, w którym te rekonstrukcje się dokonują.

Świat społeczny, jak dowodzi Paweł Rybicki, nie jest konstruktem w pełni ukształtowanym, jaskrawym w swym terminologicznym znaczeniu. „Każdy świat to jakiś zakres danej nam rzeczywistości. Rzecz w tym, że zakresy te nie są podobne do siebie, nie są nam dane w jednakowy sposób. Najważniejsza cecha, jaka może różnić światy, polega na tym, że albo to, co nazywamy światem jest nam dane w doświadczeniu jako niepodzielna jedność, albo przedstawia się nam jako wielość powiązanych ze sobą elementów”2. Nie sposób zatem jednakowo postrzegać oraz interpretować otaczającej rzeczywistości, skoro - jak chce wybitny analityk współczesności Zygmunt Bauman - „wytapia się [ona] z ludzkiego doświadczenia”3. Społeczeństwo istnieje więc jako struktura obiektywna i subiektywna, co staje się podstawowym budulcem dla społecznego tworzenia rzeczywistości ${ }^{4}$. Warunkiem zaś koniecznym dla właściwego jej rozumienia jest postrzeganie społeczeństwa jako stale dokonującego się procesu dialektycznego, którego teoriopoznawczą podstawę stanowi socjologia wiedzy. Ponadto orbity indywidualnego życia jednostek wzajemnie przenikają się z trajektoriami społecznych zmian, są wzajemnie od siebie zależne, wzajemnie też się determinują.

We współczesnej myśli socjologicznej kładziony jest nacisk na zmienność warunków działania, nietrwałość społecznych relacji, poczucie jednostkowej niepewności oraz zagrożenia bezpieczeństwa, wzajemnie przenikającą się płynność życia i płynność społeczeństwa ${ }^{5}$. Bez względu jednak na perspektywę analityczną - „żadne badanie socjologiczne, które nie wraca do problemu biografii, historii i ich krzyżowania się w ramach społeczeństwa, nie przeszło do końca swej drogi intelektualnej”。. Świat społeczny jawi się zatem jako wielość rzeczywistości spowitych w mnogość interpretacyjnych znaczeń. Konsekwencją tego jest założenie, iż człowiecza aktywność oraz jednostkowe przeżycia poj-

${ }^{1}$ S. Ossowski, O strukturze społecznej, Warszawa 1986.

2 P. Rybicki, Struktura społecznego świata. Studia z teorii społecznej, Warszawa 1979, s. 76.

3 Z. Bauman, Społeczeństwo w stanie oblężenia, Warszawa 2007, s. 38.

${ }^{4}$ Odwołuję się w ten sposób do tytułu znakomitego dzieła P.L. Bergera, T. Luckmanna, Społeczne tworzenie rzeczywistości, Warszawa 1983.

${ }^{5}$ Koncepcja „płynnej nowoczesności” zobrazowana została w dziełach Z. Baumana: Płynna nowoczesność, Kraków 2006; Płynne życie, Kraków 2007; Płynne czasy. Życie w epoce niepewności, Warszawa 2007; Płynny lęk, Kraków 2008; 44 listy ze świata płynnej nowoczesności, Kraków 2011.

${ }^{6}$ C.W. Mills, Wyobraźnia socjologiczna, Warszawa 2007, s. 53. 
mowane są „jako zmienna w czasie konstelacja najprzeróżniejszych układów i uporządkowań”, których analiza nie wyczerpuje się li tylko w zwodniczej polaryzacji obiektywne - subiektywne. Granice socjologicznego poznania dotykają także kontekstów kulturowych, zobiektywizowanych przejawów ducha dziejów, czy chociażby obarczonego systemem znaczeń kulturowych/symbolicznych języka. Jak sugeruje Anthony Giddens - „socjologia stała się odrębną dziedziną poznania wraz z powstaniem społeczeństw nowoczesnych i badanie takich społeczeństw pozostaje jej zasadniczą domeną. Jednakże socjologów interesuje też szeroki zakres zagadnień dotyczących natury interakcji społecznej i społeczeństw ludzkich w ogóle. Socjologia nie ogranicza się do abstrakcyjnych dywagacji intelektualnych. Znajduje ona wiele znaczących zastosowań praktycznych”8.

W tak rozumianą „zadaniowość” współczesnej socjologii, której jednym z elementów jest naukowy pragmatyzm, znakomicie wpisuje się najnowsza książka profesora Pawła Prüfera: Rekonstrukcja jakości życia. Teoretyczno-praktyczne atuty socjologii. Podzielona ona została na trzy główne części, które poprzedza Wstęp, zwieńczeniem dzieła jest zaś podsumowujące całość rozważań Zakończenie, obszerna, zawierająca mnogość obcojęzycznych pozycji Bibliografia, jak również streszczenie w języku ojczystym, angielskim i włoskim.

Autor we Wstępie formułuje tezę, „iż możliwość kreślenia socjologicznej perspektywy może przekładać się na poprawę jakości życia oraz wzrost poczucia dobrostanu psychospołecznego jednostek i grup społecznych. Historia ludzkości, dzieje cywilizacji oraz pewne perspektywiczne i "prognostyczno-diagnostyczne« konstrukty wychylone ku przyszłości pokazują, że wciąż ma się do czynienia z przejawami niesprawiedliwości, destrukcyjnymi podziałami, z tendencjami do forsowania koncepcji świata i społeczeństwa podzielonych na części, z których jedne uznaje się za zewnętrzne, wiodące, czyli w domyśle - ważniejsze. (...) Twierdzę ponadto, że treści socjologiczne mogą stawać się skutecznym narzędziem afirmującym życie, a tym samym promującym i waloryzującym człowieka oraz świat społeczny, w którym ten człowiek żyje i który, wraz z innymi, tworzy" (s. 10). Takie pojmowanie socjologii wymyka się trzem kluczowym płaszczyznom socjologicznego postępowania - deskrypcji, rozumieniu i wyjaśnianiu, a ukierunkowuje raczej na myślenie o aksjonormatywnych wyznacznikach regulujących postępowanie socjologa. Szeroko rozumiany horyzont poznawczy wykorzystywany oraz realizowany przez socjologię ukazany zostaje (w niezaprzeczalnie subiektywny sposób) w pierwszym rozdziale książki, zatytułowanym Osobliwości socjologii. Jego widoczne odwołanie do wybitnego dzieła Stanisława Ossowskiego O osobliwościach nauk społecznych z roku 1962 nie stanowi li tylko zabiegu natury pojęciowo-semantycznej. Jest raczej swoistą polemiką z postulowaną przez Ossowskiego „profesjonalną neutralnością” ujmowaną w kategoriach: praktyki i teorii, działacza i mędrca - stanowiących miarodajny punkt wyjścia dla inżynierii społecznej, a ponadto lokujących współczesną socjologię w odmętach procesów przemian społecznych9. Misyjność, płaszczyzna powinnościowa, czy jak chce Franco Ferrarotti - „świeckie kapłaństwo”, wypełniają zdaniem Pawła Prüfera deontologiczny wymiar aktywności współczesnego socjologa. Potwierdza tym samym, iż „socjologia jest więc bliska życiu, jest związana z życiem na tyle istotnie, iż te dwa światy splatają się ze sobą w jakimś niewidzialnym, lecz mocno odczuwalnym splocie wzajemności” (s. 19). Autor odwołuje się, za Norbertem Eliasem, do procesu społecznych figuracji dokonywanych przez jednostki w swej codziennej aktywności i praktykach społecznych; zwraca uwagę na konieczność luckmannowskiego „zdystansowania” w próbach poznania i zrozumienia otaczającego świata z całym jego bogactwem

\footnotetext{
${ }^{7}$ A. Manterys, Wielość rzeczywistości w teoriach socjologicznych, Warszawa 1997, s. 7.

8 A. Giddens, Socjologia, Warszawa 2004, s. 42.

9 Por. w tej kwestii: S. Ossowski, O osobliwościach nauk społecznych, Warszawa 1962.
} 
społecznych interakcji, nieustannym przeplataniem się biografii życiowych jednostek z trajektoriami przemian społecznych.

W poznawaniu siebie i innych, rozumieniu konieczności optymalizowania człowieczej jakości życia towarzyszyć powinna postawa pokory oraz skromności podszytych obiektywizmem i ostrożnością w operowaniu ideami, teoriami, czy też światopoglądami sugerującymi kształt schematów/ pomysłów wdrażanej strategii ulepszania świata. Autor wskazuje w tym miejscu na zwodniczość marksowskiej teorii materializmu historycznego, której ulegli w czasie systemowego reżimu niektórzy, skądinąd znakomici i zasłużeni dla rozwoju nauki rodzimi badacze, jak chociażby przytaczany przez niego Józef Chałasiński. Warto jednak - dla równowagi poznawczej i uczciwości naukowej podkreślić fakt, iż ideologicznego (u)wikłania się badaczy nie zakończył upadek szczęśliwie minionego systemu w naszym kraju. Profetyczne okazały się niestety słowa wybitnego socjologa i filozofa Theodora W. Adorno: „istnieje bowiem nie tylko wulgarny materializm, ale istnieje również wulgarny idealizm”" ${ }^{10}$, etykieta zaś „lewicowego intelektualisty” nabiera mistycznego i obsesyjnego wprost znaczenia w ustach żarliwych zwolenników o narodowo-nacjonalistycznej, radykalno-prawicowej proweniencji. Ich głos obecnie politycznie uprawomocniany staje się tym, co Umberto Eco określił mianem prafaszyzmu w cywilnych szatach ${ }^{11}$.

Opis otaczającego świata w poznaniu socjologicznym nie zawsze dokonywany jest za pomocą racjonalnego, wynikającego z tradycji nauki - narzędzia; czasami próby interpretacyjne przybierają wysoce osobliwy kształt, który Autor określił mianem „metaforycznego obrazowania świata”. Fauna i flora stanowią tutaj swoistą egzemplifikację dla zachodzących w człowieczym świecie procesów, natomiast dobra naturalne stają się punktem wyjścia dla przywołania koncepcji zrównoważonego rozwoju jako pojęcia teoretycznego określającego pożądany kierunek zmian globalnych. Zresztą idea rozwoju znajduje u Pawła Prüfera wyraźne odwołania do twórczości przywoływanego wcześniej Stanisława Ossowskiego. Niniejsze inspiracje są w analizowanym rozdziale widoczne i stanowią swoiste odniesienia do wcześniejszej książki Autora - Metamorfoza społeczeństwa. Zarys teorii maturacjonizmu linearno-cyklicznego, Warszawa 2020. Stanowią one podwaliny dla przekonania, iż społeczeństwo znajduje się $\mathrm{w}$ fazie permanentnego przeobrażania się, rozwoju wynikającego z nakładania się praw linearnych i cyklicznych, zaś ,jako społeczeństwo i jako jednostki jesteśmy we wszystkich wymiarach naszego bytu beneficjentami i nosicielami hipoteki społecznej ludzkości” (s. 38).

Autor - wskazując na konieczność dostrzegania w oglądzie socjologicznym różnorodności i piękna świata - przywołuje subdyscypliny socjologiczne zdolne trafnie oraz wielowymiarowo uchwycić jego bogactwo: socjologia miasta, socjologia religii, czy też socjologia moralności. Ich rolą jest poszerzanie i pogłębianie znaczeniowe „schematów interpretacji życia”, co pozwala ujrzeć świat w nieuproszczonej perspektywie i zrozumieć jego złożoność.

Rozdział drugi, Człowiek w społeczeństwie, koncentruje się na jednostce, rozwoju oraz społeczeństwie w kontekście treści socjologicznych stanowiących substancję znaczeniową tej dziedziny wiedzy. Ukazuje się tutaj czytelnikowi obraz człowieka jako niepowtarzalnego bytu społecznego, jako „najcenniejszego materiału cywilizacyjnego" oraz kluczowego podmiotu socjologicznych do-

10 T.W. Adorno, Nowy prawicowy radykalizm. Wykład o jego kilku aspektach, Kraków 2020, s. 27. Autor w dalszej części swego wykładu pisze: „Dzisiejsza nośność mizoginicznej i homofonicznej agitacji w epoce równouprawnienia albo renesans religijnego fundamentalizmu w naszej świeckiej teraźniejszości pokazują, jak zwodnicze jest branie raz osiągniętych zdobyczy cywilizacyjnych za coś oczywistego" (s. 77).

${ }^{11}$ Zob. U. Eco, Pięć pism moralnych, Kraków 1999. 
ciekań, zdolnego kreować zjawiska, działania, byty, czy też wreszcie więzi społeczne w rozmaitych konfiguracjach przestrzennych i czasowych. Odmienną od indywidualizmu metodologicznego ramą interpretacyjną jest podejście interakcjonistyczne i funkcjonalistyczne, które chcą widzieć człowieka jako jednostkę relacyjną i więziotwórczą, przejmującą określone funkcje oraz role społeczne w wytwarzaniu potencjału i kapitału w środowisku jej egzystencji. Autor, nawiązując do opinii uznanych autorytetów naukowych (Bruce, Hughes, Znaniecki), wspiera przekonanie i postulat, iż socjologia winna skracać dystans w naukowym poznawaniu jednostki i w całej rozciągłości koncentrować się na człowieku oraz jego życiowej aktywności. Jego podmiotowość i sprawczość widoczna jest w każdym wymiarze codziennej egzystencji, także w czynnościach zabawowych, konstytuujących spopularyzowany przez Johana Huizingę wizerunek homo ludens. Zabawa bowiem, poza zapewnieniem swoistego dobrostanu psychospołecznego i fizycznego, jest ciągiem czynności o znaczeniu podmiotowym, twórczym, określającym człowieczą tożsamość. Wszystkie te wielopłaszczyznowe formy jednostkowej aktywności nadają dynamiki nie tylko ludzkiej biografii; są także czynnikiem zmienności i mobilności całego społeczeństwa, podkreślając jego kinetyczny charakter bez względu na miejsce, epokę historyczną i moment rozwojowy (stadium). Autor odwołuje się do idei rozwoju świata, w której zespajają się ze sobą człowiecza aktywność i sprawczość oraz demiurgiczne zaangażowanie w doskonalenie ludzkiego dzieła. Perspektywę filozoficzną i antropologiczną uzupełnia zatem czynnik teologiczny określany przez Pawła Prüfera mianem „pierwiastka nadprzyrodzonego”. Rozwój cywilizacyjny - bez względu na czynniki go konstytuujące bądź też dynamizujące - wymaga stałej korekty i stymulacji. Zmienność codziennych praktyk życiowych, postęp technologiczny, czy chociażby logika ludzkiej motywacji generują potrzebę regularnej aktualizacji funkcjonowania systemu społecznego, politycznego, czy też gospodarczego. Człowiek o cechach osobowości określanej jako nowoczesna, będąc otwartym na innowacje i zmianę, świadom otaczającej go różnorodności - przekuwa doświadczenia przeszłości w działania na rzecz poprawy jakości własnego życia oraz całego społeczeństwa, w którym funkcjonuje. Jak obrazowo konkluduje Autor - „reprodukcja tkanki społecznej jest możliwa dlatego, że ziarno uspołecznienia jest potencjałem zdeponowanym w ontologicznej strukturze jednostki” (s. 102).

Szczególnie interesujący z uwagi na oryginalną perspektywę badawczą wydaje się być trzeci rozdział książki zatytułowany: Wiedza przedsocjologiczna - socjologiczna wartość treściowa. Stanowi on świadectwo nieprzeciętnej erudycji Autora i jest niepodważalnym dowodem jego wkładu w nieortodoksyjne uprawianie socjologii jako nauki zdolnej do poprawy człowieczego życia. Odwołuje się Paweł Prüfer do pojęcia wiedzy przedsocjologicznej, która za Piotrem Sztompką przyjmuje trojaką postać: wiedzy potocznej, wrażliwości artystycznej i wreszcie - refleksji filozoficznej ${ }^{12}$. I to właśnie literatura piękna stała się tutaj swoistym źródłem, miejscem „ekranizacji” ${ }^{13}$ wiedzy na temat różnorakich zagadnień mających dla socjologii nieprzeciętną wartość, jak chociażby: przechodniośćl cykliczność etapów życia; niepowtarzalność ludzkiej biografii; sakralizacja przestrzeni życia i rytualność; skuteczność działania i manipulowanie; fatalizm i podejmowanie wysiłku przez człowieka oraz jego aktywność i sprawczość; odgrywanie ról społecznych w kontekście autonomii i rozmaitych czynników motywacyjnych; rozwój technologiczny oraz jego afirmacja; związki człowieka

${ }_{12}$ Szersze omówienie cech przedsocjologicznej wiedzy o społeczeństwie w: P. Sztompka, Socjologia. Analiza społeczeństwa, Kraków 2002, s. 18 i nast.

${ }^{13}$ Określenie zaczerpnięte od Lecha Witkowskiego, oznaczające strategię poszukiwania problemu wybuchowości w kontekstach kulturowych - L. Witkowski, Wybuchowe idee dla pedagogiki i edukacji a procesy rozwoju duchowego, „Orbis Idearum” 2021, vol. 9, issue 1, s. 123-143. 
z przestrzenią; ewolucja/postęp/progres a logika rozwojowa; władza, prestiż i bogactwo w hierarchii człowieczych potrzeb; uwarunkowania stratyfikacji społecznej; pojmowanie wspólnoty oraz czynników ją kreujących i zespalających; adaptacja i symbioza ze środowiskiem społecznym; umiejętność odnalezienia się jednostki w nowej rzeczywistości; percepcja świata w kontekście nadawania znaczeń i stawania się świadomym siebie. Zobrazowania niniejszej tematyki Autor doszukiwał się w dziełach literatury rodzimej i światowej różnych krajów oraz epok. Podstawą do konstruowania socjologicznych uogólnień były powieści, reportaże, wiersze i dramaty takich pisarzy, jak: Tadeusz Konwicki, Julio Cortázar, Cyprian Kamil Norwid, William Faulkner, Robert Louis Stevenson, William Szekspir, Owidiusz, Joanna Chmielewska, Hermann Hesse, Joseph Heller, Michaił Lermontow, Emil Zola, George Orwell, Johann Wolfgang Goethe, Heinrich Böll, Lew Tołstoj, Homer, Stanisław Wyspiański, Władysław Reymont, Gabriel Garcia Márquez, Bohumil Hrabal, Herbert George Wells, August Strindberg, James Jones, Honoré de Balzac, Graham Greene, Joseph Conrad, Ryszard Kapuściński, Jarosław Iwaszkiewicz, Milan Kundera, Charles Dickens czy Oscar Wilde. Imponująca mnogość przytaczanej literatury wraz z zawartą w niej i skrzętnie przez Pawła Prüfera wyłuskaną wiedzą przedsocjologiczną pozwoliły w kontekście różnorodnych teorii (interakcjonizmu symbolicznego, etnometodologii, funkcjonalizmu, czy też teorii konfliktu) ukazać nieprzebrane bogactwo świata społecznego.

Książka profesora Pawła Prüfera - Rekonstrukcja jakości życia. Teoretyczno-praktyczne atuty socjologii - jest opracowaniem wyjątkowym na rodzimym rynku z uwagi na swój interdyscyplinarny charakter, zastosowaną metodę i perspektywę oglądu świata. Z jednej strony ma przejrzysty i nad wyraz czytelny układ, z drugiej zaś - odważnie ukazuje rolę i miejsce współczesnej socjologii w procesie kształtowania, weryfikowania oraz ulepszania jakości człowieczego życia. Nieskrywany humanizm, troska i wrażliwość Autora na dysharmonie świata społecznego, których efektem jest destrukcyjny lęk, niezawinione cierpienie i arytmia ludzkiej egzystencji, lokują niniejszą książkę w zaszczytnej kategorii intelektualnego wezwania o lepszy świat i naukowej walki z jego niegodziwościami. Jak przekonuje bowiem Zygmunt Bauman: „przyglądanie się ze spokojem ludzkiemu cierpieniu przy jednoczesnym łagodzeniu wyrzutów sumienia powtarzaniem rytualnego zaklęcia, że "nie ma innego wyjścia«, oznacza współodpowiedzialność. Ktokolwiek świadomie lub mimo woli maskuje albo, co gorsza, neguje to, iż każdy porządek społeczny, zwłaszcza zaś ten, który odpowiada za ludzkie cierpienie, ma czysto ludzki, nigdy nie ostateczny, przygodny i poddający się zmianom charakter, dopuszcza się czynu niemoralnego, gdyż odmawia niesienia pomocy osobom potrzebującym. Sens uprawiania socjologii tkwi w odkrywaniu możliwości współżycia z różnorodnością przy jednoczesnym ograniczaniu lub całkowitym eliminowaniu cierpienia" ${ }^{14}$. Perspektywa o d p o w i e d z i a ln o ś c i nauki za ład i społeczny porządek świata zawarta w niniejszej książce wyznacza zatem możliwe kierunki dalszego rozwoju refleksji socjologicznej oraz orientacji badawczej naukowca socjologa - humanisty.

Piotr Mosiek

DOI: 10.14746/psn.2021.2.13

14 Z. Bauman, Płynna nowoczesność, op. cit., s. 332-333. 